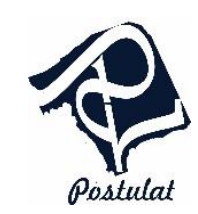

Jurnal Inovasi Pendidikan Matematika

Volume 1, Nomor 1, Juli 2020

\title{
Analisis Kesalahan Peserta Didik Dalam Menyelesaikan Masalah Matematika Berdasarkan Tahapan Newman Ditinjau Dari Perbedaan Gender
}

\author{
Sumila Eka Yuni Arianti \\ SDN Kembangan; Jl. Mayjen Sungkono 18, Kembangan, Kec. Kebomas, Kab. Gresik Prov. Jawa \\ Timur 61161; sumilaeka.yuniarianti@gmail.com
}

\begin{abstract}
The error is case that students often do in solving mathematics' problem. In solving mathematics' problem everybody has different way in thinking process, especially based on gender. On the way that used in analyze the error that students do like Newman step, Newman step could know the error of the students through 5 steps, such as reading, comprehension, transformation, process skill and encoding. The purpose of this research is to know where is the error of male students and female students in solving mathematics' problem in Algebra in class VII-D at SMP Muhammadiyah 1 Gresik. The research is descriptive quantitative. The subject of this research are students of SMP Muhammadiyah 1 Gresik class VII-D, the total of the students are 22 students. Method of the research are test and interview. The instrument used in this research are solving mathematic problem test, validation sheet, interview items. The result from analysis data, male students get the reading error 0\%, comprehension $68.81 \%$, transformation $90.91 \%$, process skill $90.91 \%$ and encoding $81,82 \%$. Meanwhile, female students get the reading error 0\%, comprehension $27.27 \%$, transformation $72.73 \%$, process skill $54.54 \%$ and encoding $45.46 \%$. So, the big error the male students is the step of transformation and process skill. Meanwhile the big error the female students is the step of transformation.
\end{abstract}

Key Words: Error, mathematics' problem, Newman step, the different gender

\begin{abstract}
Abstrak
Kesalahan merupakan kejadian yang sering dilakukan peserta didik ketika menyelesaikan masalah matematika. Penyelesaian masalah khususnya masalah matematika setiap individu memiliki pola berpikir yang berbeda-beda, terutama jika dilihat dari gender. Salah satu tahapan yang dapat digunakan untuk menganalisis kesalahan yang dilakukan peserta didik yaitu dengan tahapan Newman, dimana tahapan Newman dapat mengetahui letak kesalahan peserta didik melalui 5 tahapan yaitu membaca, memahami, mentransformasi, proses pekerjaan, dan penulisan jawaban akhir. Tujuan penelitian ini adalah untuk mengetahui letak kesalahan peserta didik laki-laki dan perempuan dalam menyelesaikan masalah matematika pada materi Aljabar dikelas VII-D SMP Muhammadiyah 1 Gresik. Penelitian ini merupakan penelitian deskriptif kuantitatif. Subjek pada penelitian ini adalah seluruh peserta didik kelas VII-D SMP Muhammadiyah 1 Gresik sebanyak 22 peserta
\end{abstract}


Sumila Eka Yuni Arianti : Analisis Kesalahan Peserta Didik...

didik. Metode yang digunakan adalah metode tes dan wawancara. Instrumen yang digunakan dalam penelitian ini adalah tes penyelesaikan masalah matematika, lembar validasi, dan pedoman wawancara. Dari hasil analisis data, peserta didik laki-laki mengalami kesalahan pada tahapan membaca $0 \%$, memahami masalah 68,81\%, mentranformasi $90,91 \%$, keterampilan proses $90,91 \%$ dan penulisan jawaban akhir $81,82 \%$. Sedangkan, pada peserta didik perempuan mengalami kesalahan pada tahapan membaca $0 \%$, memahami masalah $27,27 \%$, mentranformasi $72,73 \%$, keterampilan proses $54,54 \%$ dan penulisan jawaban akhir $45,46 \%$. Jadi kesalahan terbesar yang dialami peserta didik laki-laki terletak pada tahapan transformasi dan proses pekerjaan. Sedangkan kesalahan terbesar yang dialami peserta didik perempuan terletak pada tahapan transformasi.

Kata kunci: kesalahan, masalah matematika, tahapan Newman, perbedaan gender.

INFO ARTIKEL

ISSN $: 2733-0597$
e-ISSN $: 2733-0600$
DOI $:$ http://dx.doi.org/10.30587/postulat.v1i1.1681

Submit Artikel:

2 April 2020

Submit Revisi:

17 Juni 2020

Upload Artikel:

26 Juni 2020

\section{A. PENDAHULUAN}

Matematika merupakan ilmu wajib yang harus ada di dunia pendidikan. Jadi tidak heran jika matematika sudah kita pelajari sejak di sekolah dasar hingga ke perguruan tinggi. Menurut Rostina Sundayana (2015: 2) "matematika merupakan salah satu bidang studi yang mendukung perkembangan ilmu pengetahuan dan teknologi’”.

Tujuan diberikan mata pelajaran matematika kepada peserta didik karena matematika berhubungan erat dengan kehidupan sehari-hari. Maka dari itu hendaknya guru memberikan latihan yang bersifat pemecahan masalah kepada peserta didik agar mereka terbiasa ketika menghadapi masalah yang berhubungan dengan matematika dalam kehidupannya.

Ketika proses belajar mengajar pada mata pelajaran matematika, seorang guru tidak boleh memarahi peserta didiknya jika mengalami kesalahan ketika menyelesaikan masalah matematika, namun guru harus membantu peserta didik dalam menemukan letak kesalahan yang terjadi ketika menyelesaikan masalah matematika agar kesalahan tersebut tidak terulang kembali. Penyelesaian masalah khususnya masalah matematika pada setiap individu memiliki pola berpikir yang berbeda-beda, terutama jika dilihat dari gender. 
Proses belajar gender pada diri anak dimulai dari anak tersebut masuk sekolah hingga berlanjut pada pendidikan selanjutnya. Perbedaan perilaku antara laki-laki dan perempuan di kelas akan menimbulkan ketimpangan gender. Berikut pandangan dari Myra dan David Sadker (Santrock, 2007: 91), mengenai adanya bias terhadap anak perempuan, yaitu:

1. Di dalam kelas biasanya anak perempuan lebih tertib, patuh, diam dan sabra dalam menunggu giliran. Sedangkan anak laki-laki lebih ribut dan lebih meminta perhatian dari gurunya. Sehingga guru lebih condong ke anak laki-laki untuk menegur dan memarahi mereka.

2. Di banyak kelas, guru menghabiskan lebih banyak waktu untuk memperhatikan dan berinteraksi dengan peserta didik laki laki dibandingkan ke peserta didik perempuan, peserta didik perepuan dibiarkan mengerjakan secara mandiri. Kebanyakan guru lebih menguntungkan peserta didik laki-laki karena di dalam kelas guru lebih banyak menghabiskan waktu dengan mereka.

3. Dibandingkan anak perempuan, anak laki-laki lebih banyak menerima bantuan ketika mereka mengalami kesulitan ketika mengerjakan atau menjawab pertanyaan. Guru sering kali memberi waktu yang lama kepada anak laki-laki ketika menjawab pertanyaan sampai jawabannya benar.

Menurut Khodijah (2011: 187), mengemukakan bahwa berdasarkan gender karakteristik laki-laki dan perempuan memang berbeda. Peserta didik perempuan akan lebih rajin daripada peserta didik laki-laki. Selain itu, antara laki-laki dan perempuan memiliki kemampuan yang berbeda-beda dalam hal menyerap materi matematika yang diajarkan.

Adanya kesalahan ketika menyelesaikan masalah matematika yang dilakukan oleh peserta didik laki- laki dan perempuan akan mengetahui sampai sejauh mana mereka memahami materi yang disampaikan. Salah satu cara yang dapat dilakukan untuk mengetahui kesalahan yaitu dengan menganalisis letak kesalahan yang terjadi. Ada beberapa tahapan yang dapat digunakan untuk menentukan kesalahan salah satunya yaitu dengan menggunakan tahapan newman, dimana tahapan ini dapat membantu menemukan kesalahan yang terjadi pada pekerjaan peserta didik ketika menyelesaikan masalah matematika. 
Sumila Eka Yuni Arianti : Analisis Kesalahan Peserta Didik...

Tahapan newman merupakan tahapan yang dikembangkan oleh Anne Newman pada tahun 1977. Tahapan Newman digunakan untuk memahami dan menganalisis bagaimana peserta didik memecahkan masalah matematika. Menurut Newman (dalam White, 2010), letak kesalahan dalam pemecahan masalah dapat terjadi pada salah satu tahap berikut: tahap membaca (reading), memahami (comprehension), transformasi (transformation), keterampilan proses (process skill) dan menuliskan solusi/jawaban (solution).

Tahapan tersebut dapat digunakan untuk menganalisis kesalahan peserta didik ketika menyelesaikan masalah khususnya pada masalah matematika yang memerlukan tahapantahapan dalam penyelesaiannya. Salah satu materi dalam matematika yang memerlukan tahapan-tahapan penyelesaian ketika mengerjakannya adalah materi aljabar. Aljabar merupakan materi kelas VII SMP semester Ganjil yang banyak sekali hubungannya dalam kehidupan sehari-hari sehingga memerlukan langkah penyelesaian yang tepat agar masalah tersebut segera teratasi

\section{B. METODE PENELITIAN}

Jenis penelitian ini adalah penelitian deskriptif kuantitatif yang bertujuan untuk memaparkan atau mendeskripsikan tentang letak serta persentase kesalahan peserta didik dalam menyelesaikan masalah matematika berdasarkan tahapan Newman ditinjau dari pengurangan perkalian dan pembagian bentuk aljabar.

Instrumen yang digunakan dalam penelitian ini adalah tes menyelesaikan masalah matematika, lembar validasi soal dan pedoman wawancara. Tes menyelesaikan masalah matematika terdiri dari 2 soal berbentuk uraian dan sesuai dengan kurikulum 2013.

Metode analisis data yang digunakan pada penelitian ini yaitu metode analisis hasil tes menyelesaikan masalah matematikaa dan metode analisis hasil wawancara. Analisis hasil tes kemampuan matematika yang telah dikerjakan oleh subjek penelitian, dilakukan untuk mengetahui nilai tes menyelesaikan masalah matematika dengan memperhatikan tahapantahapan Newman. Jawaban peserta didik dalam menyelesaikan masalah dimasukkan ke dalam 3 kategori, yaitu: 
a. Peserta didik menjawab benar, jika peserta didik tidak melakukan kesalahan pada setiap langkah penyelesaian masalah.

b. Peserta didik menjawab, jika peserta didik melakukan kesalahan pada langkah penyelesaian masalah.

c. Peserta didik tidak menjawab, jika peserta didik tidak menjawab atau mengerjakan masalah yang diberikan.

Dalam penelitian ini yang dianalisis adalah peserta didik yang menjawab salah dan tidak menjawab masalah yang diberikan. Peserta didik yang mengerjakan masalah dengan benar tidak perlu dianalisis. Jika seseorang peserta didik memenuhi kategori 2 dan 3 maka pada kategori itu diberi "poin 1". Sedangkan peserta didik yang memenuhi kategori 1 diberi "poin 0".

\section{HASIL PENELITIAN}

Data yang dianalisis pada penelitian ini tidak berupa skor yang didapatkan peserta didik melainkan lebih memperhatikan pada kesalahan yang ada dalam menyelesaikan masalah matematika pada materi pokok aljabar. Hasil tes tersebut sebagai berikut:

Tabel 1 Distribusi kesalahan berdasarkan letak Kesalahan

\begin{tabular}{|c|c|c|c|c|c|c|c|c|c|c|c|c|}
\hline \multicolumn{13}{|c|}{ PESERTA DIDIK LAKI-LAKI } \\
\hline \multirow{2}{*}{$\begin{array}{l}\text { No. } \\
\text { Abs }\end{array}$} & \multirow{2}{*}{ Ket } & \multicolumn{5}{|c|}{ Soal 1} & \multicolumn{5}{|c|}{ Soal 2} & \multirow{2}{*}{$\mathrm{Jm}$} \\
\hline & & $\mathrm{a}$ & b & $\mathrm{c}$ & $\mathrm{d}$ & $\mathrm{e}$ & A & b & $\mathrm{c}$ & $\mathrm{d}$ & $\mathrm{e}$ & \\
\hline 1. & & 0 & 1 & 1 & 1 & 1 & 0 & 1 & 1 & 1 & 1 & 8 \\
\hline 5. & & 0 & 1 & 1 & 1 & 1 & 0 & 0 & 1 & 1 & 0 & 6 \\
\hline 7. & & 0 & 1 & 1 & 1 & 1 & 0 & 0 & 1 & 1 & 1 & 7 \\
\hline 8. & & 0 & 1 & 1 & 1 & 1 & 0 & 0 & 1 & 1 & 1 & 7 \\
\hline 10. & & 0 & 1 & 1 & 1 & 1 & 0 & 0 & 1 & 1 & 1 & 7 \\
\hline 11. & & 0 & 1 & 1 & 1 & 1 & 0 & 1 & 1 & 1 & 0 & 7 \\
\hline 12. & & 0 & 1 & 1 & 1 & 1 & 0 & 1 & 1 & 1 & 1 & 8 \\
\hline 13. & & 0 & 1 & 1 & 1 & 1 & 0 & 0 & 1 & 1 & 1 & 7 \\
\hline 14. & & 0 & 1 & 1 & 1 & 1 & 0 & 1 & 0 & 0 & 0 & 5 \\
\hline
\end{tabular}


Sumila Eka Yuni Arianti : Analisis Kesalahan Peserta Didik...

\begin{tabular}{|l|l|l|l|l|l|l|l|l|l|l|l|l|}
\hline 15. & & 0 & 1 & 1 & 1 & 1 & 0 & 0 & 1 & 1 & 1 & 7 \\
\hline 16. & & 0 & 1 & 0 & 0 & 0 & 0 & 0 & 1 & 1 & 1 & 4 \\
\hline
\end{tabular}

\begin{tabular}{|c|c|c|c|c|c|c|c|c|c|c|c|c|}
\hline \multicolumn{13}{|c|}{ PESERTA DIDIK PEREMPUAN } \\
\hline \multirow[b]{2}{*}{$\begin{array}{l}\text { No. } \\
\text { Abs }\end{array}$} & \multirow[b]{2}{*}{ Ket } & \multicolumn{5}{|c|}{ Soal 1} & \multicolumn{5}{|c|}{ Soal 2} & \multirow[b]{2}{*}{$\mathrm{Jml}$} \\
\hline & & $\mathrm{a}$ & $\mathrm{b}$ & $c$ & $d$ & $\mathrm{e}$ & $\mathrm{A}$ & b & $\mathrm{c}$ & $\mathrm{d}$ & $\mathrm{e}$ & \\
\hline 2. & & 0 & 1 & 1 & 0 & 0 & 0 & 0 & 1 & 1 & 1 & 5 \\
\hline 3. & & 0 & 0 & 1 & 0 & 0 & 0 & 0 & 1 & 0 & 0 & 2 \\
\hline 4. & & 0 & 0 & 0 & 0 & 0 & 0 & 0 & 1 & 1 & 1 & 3 \\
\hline 6. & & 0 & 0 & 0 & 0 & 0 & 0 & 0 & 1 & 1 & 0 & 2 \\
\hline 9. & & 0 & 1 & 0 & 1 & 1 & 0 & 0 & 1 & 1 & 1 & 6 \\
\hline 17. & & 0 & 1 & 1 & 0 & 0 & 0 & 0 & 1 & 1 & 1 & 5 \\
\hline 18. & & 0 & 0 & 0 & 1 & 1 & 0 & 0 & 1 & 1 & 1 & 5 \\
\hline 19. & & 0 & 0 & 0 & 0 & 0 & 0 & 1 & 1 & 0 & 0 & 2 \\
\hline 20. & & 0 & 0 & 1 & 0 & 0 & 0 & 0 & 1 & 1 & 1 & 4 \\
\hline 21. & & 0 & 1 & 0 & 0 & 0 & 0 & 0 & 1 & 1 & 0 & 3 \\
\hline 22 & & 0 & 0 & 1 & 1 & 1 & 0 & 1 & 1 & 1 & 1 & 7 \\
\hline
\end{tabular}

\section{Keterangan:}

$\mathrm{a}=$ Letak kesalahan membaca soal

$\mathrm{b}=$ Letak kesalahan memahami soal

$\mathrm{c}=$ Letak kesalahan mentranformasi

$\mathrm{d}=$ Letak kesalahan proses penyelesaian

$\mathrm{e}=$ Letak kesalahan penulisan jawaban

akhir
1 = Peserta didik yang jawabannya salah

dan tidak menjawab

$0=$ Peserta didik yang jawabannya benar

No. Abs $=$ Nomor urut peserta didik

$\mathrm{Jml}=\mathrm{Jumlah}$ total kesalahan

Ket.= Keterangan $(\mathrm{i}=\mathrm{izin}, \mathrm{A}=$ tidak masuk $)$ 
Dari data yang disajikan pada tabel 1 selanjutya dilakukan perhitungan untuk mendapatkan jumlah dari banyaknya kesalahan dalam menyelesaikan masalah matematika pada materi pokok Aljabar. Adapaun hasil perhitungan kesalahan pada tiap tahapan disajikan dalam tabel berikut:

Tabel 2 Banyaknya kesalahan peserta didik dan persentase dalam menyelesaikan masalah matematika menurut letak kesalahan Newman

\begin{tabular}{|c|c|c|c|c|}
\hline \multirow{2}{*}{$\begin{array}{c}\text { No. } \\
\text { Soal }\end{array}$} & \multicolumn{3}{|c|}{ Memahami } & \multicolumn{2}{c|}{ Perempuan } \\
\cline { 2 - 5 } & $\begin{array}{c}\text { Jumlah } \\
\text { jawaban salah }\end{array}$ & $\begin{array}{c}\text { Persentase } \\
\text { jawaban salah } \\
(\%)\end{array}$ & $\begin{array}{c}\text { Jumlah } \\
\text { jawaban salah }\end{array}$ & $\begin{array}{c}\text { Persentase jawaban } \\
\text { salah (\%) }\end{array}$ \\
\hline 1 & 11 & 100 & 4 & 36,36 \\
\hline 2 & 4 & 36,36 & 2 & 18,18 \\
\hline Rata-rata & 8 & 68,18 & 3 & 27,27 \\
\hline
\end{tabular}

\begin{tabular}{|c|c|c|c|c|}
\hline \multirow{2}{*}{$\begin{array}{c}\text { No. } \\
\text { Soal }\end{array}$} & \multicolumn{4}{|c|}{ Mentransformasi } \\
\cline { 2 - 5 } & $\begin{array}{c}\text { Lumlah } \\
\text { jawaban salah }\end{array}$ & $\begin{array}{c}\text { Persentase } \\
\text { jawaban salah } \\
(\%)\end{array}$ & $\begin{array}{c}\text { Jumlah } \\
\text { jawaban salah }\end{array}$ & $\begin{array}{c}\text { Persentase jawaban } \\
\text { salah (\%) }\end{array}$ \\
\hline 1 & 10 & 90,91 & 5 & 45,46 \\
\hline 2 & 10 & 90,91 & 11 & 100 \\
\hline Rata-rata & 10 & 90,91 & 8 & 72,73 \\
\hline
\end{tabular}

\begin{tabular}{|c|c|c|c|c|}
\hline \multirow{2}{*}{$\begin{array}{c}\text { No. } \\
\text { Soal }\end{array}$} & \multicolumn{4}{|c|}{ Proses Pekerjaan } \\
\cline { 2 - 5 } & $\begin{array}{c}\text { Lumlah } \\
\text { jawaban salah }\end{array}$ & $\begin{array}{c}\text { Persentase } \\
\text { jawaban salah } \\
(\%)\end{array}$ & $\begin{array}{c}\text { Jumlah } \\
\text { jawaban salah }\end{array}$ & $\begin{array}{c}\text { Persentase jawaban } \\
\text { salah (\%) }\end{array}$ \\
\hline 1 & 10 & 90,91 & 3 & 27,27 \\
\hline 2 & 10 & 90,91 & 9 & 81,82 \\
\hline Rata-rata & 10 & 90,91 & 6 & 54,54 \\
\hline
\end{tabular}


Sumila Eka Yuni Arianti : Analisis Kesalahan Peserta Didik...

\begin{tabular}{|c|c|c|c|c|}
\hline \multirow{2}{*}{$\begin{array}{c}\text { No. } \\
\text { Soal }\end{array}$} & \multicolumn{3}{|c|}{ Laki-laki } & \multicolumn{2}{c|}{ Perempuan } \\
\cline { 2 - 5 } & $\begin{array}{c}\text { Jumlah } \\
\text { jawaban salah }\end{array}$ & $\begin{array}{c}\text { Persentase } \\
\text { Jawaban salah } \\
(\%)\end{array}$ & $\begin{array}{c}\text { Jumlah } \\
\text { Jawaban salah }\end{array}$ & $\begin{array}{c}\text { Persentase jawaban } \\
\text { salah (\%) }\end{array}$ \\
\hline 1 & 0 & 0 & 0 & 0 \\
\hline 2 & 0 & 0 & 0 & 0 \\
\hline Rata-rata & 0 & 0 & 0 & 0 \\
\hline
\end{tabular}

Berdasarkan tabel 2 tersebut dapat diketahui bahwa peserta didik laki-laki dan perempuan tidak ada yang mengalami kesalahan pada tahapan membaca soal. Kemudian pada tahapan memahami soal, kesalahan terbesar yang dialami peserta didik laki-laki terdapat pada soal nomor 1 dengan persentase sebesar $100 \%$ dan pada peserta didik perempuan kesalahan memahami soal terdapat pada soal nomor 1 dengan persentase sebesar $36,36 \%$. Pada tahapan mentransformasi soal kesalahan terbesar yang dialami peserta didik laki-laki terdapat pada kedua soal dengan persentase sebesar 90,91\% dan peserta didik perempuan mengalami kesalahan terbesar pada tahapan mentransformasi soal terdapat pada soal nomor 2 dengan persentase sebesar $100 \%$. Pada tahapan proses pekerjaan kesalahan terbesar yang dialami peserta didik laki-laki terdapat pada kedua soal dengan persentase sebesar 90,91\% dan peserta didik perempuan mengalami kesalahan terbesar pada tahapan proses pekerjaan terdapat pada soal nomor 2 dengan persentase sebesar 81,82\%. Pada tahapan penulisan jawaban akhir kesalahan terbesar yang dialami peserta didik laki-laki terdapat pada soal nomor 1 dengan persentase sebesar 90,90\% dan peserta didik perempuan mengalami kesalahan terbesar pada tahapan penulisan jawaban akhir terdapat pada soal nomor 2 dengan persentase sebesar $63,64 \%$.

Analisis kesalahan pada penelitian ini dilakukan pada empat tahapan dalam menyelesaikan masalah matematika pokok bahasan Aljabar. Tahapan-tahapan tersebut adalah membaca (reading), memahami masalah (comprehension), transformasi masalah (transformation), keterampilan proses (process skill), penulisan jawaban (encoding). Adapun hasil analisis tes selengkapnya sebagai berikut: 


\section{Analisis Letak Kesalahan Peserta Didik Laki-laki}

1. Tahapan Membaca (reading)

Kesalahan membaca yaitu kesalahan yang dilakukan peserta didik pada saat membaca soal. Kesalahan membaca terjadi ketika peserta didik tidak mampu membaca kata-kata maupun simbol yang terdapat dalam soal. Pada kesalahan membaca ini semua peserta didik laki-laki tidak ada kesalahan dan bisa membaca semua. Terlihat pada hasil wawancara ketika peserta didik laki-laki disuruh membaca soal nomor 1 tidak ada kesalahan dalam pengucapan kata pada soal.

2. Tahapan Memahami Masalah (comprehension)

Pada tahapan memahami masalah dari soal nomor 1 ini semua peserta didik lakilaki mengalami kesalahan padahal pada tahapan membaca tidak ada peserta didik yang mengalami kesalahan.. Adapun contoh kesalahan yang dilakukan peserta didik dapat dilihat pada gambar berikut

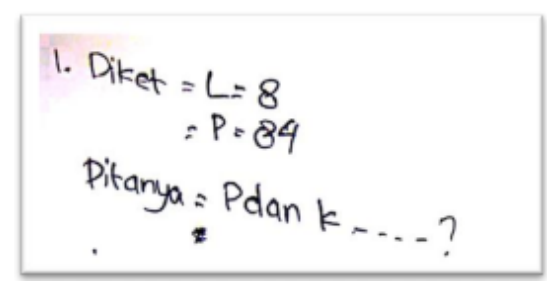

Gambar Hasil kerja Peserta didik

Setelah itu dilakukan wawancara kepada peserta didik. Dari hasil wawancara tersebut dapat diketahui bahwa dia kurang teliti dalam membaca soal dan kurangnya pemahaman terhadap soal.

3. Tahapan Transformasi Masalah (transformation)

Pada tahapan transformasi masalah terdapat 10 peserta didik laki-laki yang mengalami kesalahan dan sisanya 1 peserta didik laki-laki jawabannya benar. 10 peserta didik yang mengalami kesalahan pada tahapan transformasi masalah juga mengalami kesalahan pada tahapan memhami masalah. Kemudian 1 peserta didik yang tidak mengalami kesalahan pada tahapan transformasi masalah mengalami kesalahan pada 
Sumila Eka Yuni Arianti : Analisis Kesalahan Peserta Didik...

tahapan sebelumnya yaitu memahami masalah. Salah satu kesalahan pada tahapan transformasi masalah dapat dilihat pada gambar berikut

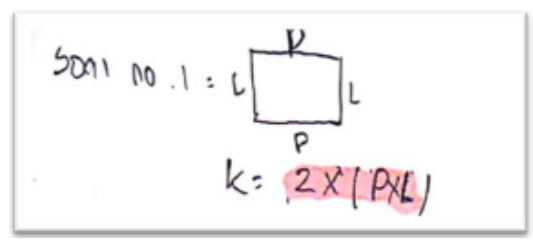

Dari hasil wawancara tersebut, dia memberi alasan bahwa masih kebingungan mengubah soal ke dalam model matematika.

4. Tahapan Keterampilan Proses (process skill)

Pada tahapan keterampilan proses terdapat 10 peserta didik laki-laki yang mengalami kesalahan dan 1 peserta didik laki-laki yang jawabannya benar. Peserta didik yang mengalami kesalahan pada tahapan keterampilan proses juga mengalami kesalahan pada tahapan mentransformasi masalah, kemudian 1 peserta didik laki-laki yang tidak mengalami kesalahan pada tahapan proses pekerjaan juga tidak mengalami kesalahan pada tahapan mentransformasi, tetapi ia mengalami kesalahan pada tahapan memahami masalah. Salah satu contoh kesalahan tersebut dapat dilihat pada gambar berikut.

$$
\begin{aligned}
& k=2 x(P+L) \\
& 84=2 P * 2 L \\
& 84=2(x)+2(8-x) \\
& 84=2 x-16+2 x \\
& 84=4 x-16 \\
& 84=16=34 m_{1}
\end{aligned}
$$

Dari hasil wawancara tersebut dia mengira bahwa jawabanya sudah benar, tetapi ternyata jawabannya salah. Dia mengalami kesalahan ketika merubah tanda yang awalnya negatif terus berpindah ruas menjadi positif. 
5. Tahapan Penulisan Jawaban Akhir (encoding)

Pada tahapan penulisan jawaban akhir terdapat 10 peserta didik laki-laki yang mengalami kesalahan dan 1 peserta didik laki-laki menjawab dengan benar. 10 peserta didik laki-laki yang mengalami kesalahan pada tahapan penulisan jawaban akhir juga mengalami kesalahan pada tahapan memahami masalah, mentransformasi dan proses pekerjaan, sedangkan 1 peserta didik laki-laki yang tidak mengalami kesalahan sebelumnya mengalami kesalahan pada tahapan memahami soal tetapi ia tidak mengalami kesalahan pada tahapan mentransformasi dan proses pekerjaan. Salah satu kesalahan penulisan jawaban dapat dilihat pada gambar berikut.

$$
\begin{aligned}
& 100 \div 4=4 \\
& 4=25
\end{aligned}
$$

Dari hasil mereka hanya wawancara, dia mengira yang harus di cari hanya panjangnya saja, jadi lebarnya tidak dia kerjakan. Berikut ini diberikan table presentase jawaban peserta didik menurut letak kesalahan pada tiap butir soal

Tabel 3 Persentase jawaban peserta didik laki-laki menurut letak kesalahan pada tiap butir soal

\begin{tabular}{|c|c|c|c|c|c|}
\hline \multirow{2}{*}{ No. Soal } & \multicolumn{5}{|c|}{ Letak Kesalahan (\%) } \\
\cline { 2 - 6 } & $\mathrm{a}$ & $\mathrm{b}$ & $\mathrm{c}$ & $\mathrm{d}$ & $\mathrm{e}$ \\
\hline 1 & 0 & 100 & 90,91 & 90,91 & 90,90 \\
\hline 2 & 0 & 36,36 & 90,91 & 90,91 & 72,73 \\
\hline Rata- rata & 0 & 68,18 & 90,91 & 90,91 & 81,82 \\
\hline
\end{tabular}

Berdasarkan tabel 3 dan analisis letak soal nomor 1 dan 2 didapat bahwa kesalahan terbesar yang dialami peserta didik laki-laki dalam menyelesaikan masalah matematika materi pokok aljabar terdapat pada letak kesalahan mentransformasi dan proses pekerjaan yaitu dengan persentase $90,91 \%$. 
Sumila Eka Yuni Arianti : Analisis Kesalahan Peserta Didik...

Tabel 4 Persentase jawaban peserta didik perempuan menurut letak kesalahan pada tiap butir soal

\begin{tabular}{|c|c|c|c|c|c|}
\hline \multirow{2}{*}{ No. Soal } & \multicolumn{5}{|c|}{ Letak Kesalahan (\%) } \\
\cline { 2 - 6 } & $\mathrm{a}$ & $\mathrm{b}$ & $\mathrm{c}$ & $\mathrm{d}$ & $\mathrm{e}$ \\
\hline 1 & 0 & 36,36 & 45,45 & 27,27 & 27,27 \\
\hline 2 & 0 & 18,18 & 100 & 81,82 & 63,64 \\
\hline Rata- rata & 0 & 27,27 & 72,73 & 54,54 & 45,46 \\
\hline
\end{tabular}

Berdasarkan tabel 4 dan analisis letak soal nomor 1 dan 2 didapat bahwa kesalahan terbesar yang dialami peserta didik perempuan dalam menyelesaikan masalah matematika materi pokok aljabar terdapat pada letak kesalahan mentransformasi yaitu dengan persentase $72,73 \%$.

\section{KESIMPULAN, DISKUSI DAN REKOMENDASI}

Berdasarkan hasil analisis data tentang letak kesalahan peserta didik laki-laki dan perempuan dalam menyelesaikan masalah matematika materi pokok Aljabar, maka diperoleh simpulan sebagai berikut:

1. Peserta didik laki-laki maupun perempuan tidak melakukan kesalahan pada tahapan pertama yaitu membaca soal. Dari analisis diketahui bahwa mereka dapat membaca semua.

2. Letak kesalahan dalam menyelesaikan masalah matematika materi Aljabar lebih di dominasi pada letak kesalahan mentransformasi dan proses pekerjaan dengan persentase lebih besar laki-laki dari pada perempuan.

3. Peserta didik di SMP Muhammadiyah 1 Gresik dalam menyelesaikan masalah matematika berdasarkan tahapan Newman lebih sering melewati tahapan mentransformasi soal. Hal ini disebabkan karena mereka masih kebingungan dengan merubah soal ke dalam model matematika dan kurangnya pemahaman pada soal. 


\section{E. DAFTAR PUSTAKA}

Abdurrahman, Mulyono. 2003. Pendidikan Bagi Anak Berkesulitan Belajar. Jakarta: Rineka Cipta.

Boaler, J. 2009. What's Math Go to Do With It? How Parents and Teacher Can Help Children Learn to Love Their Least Favorite Subject. New York: Penguin.

Browning, Geil, Ph.D. 2016. Emergenetics: Menyadapat Ilmu Kesuksesan Baru. Jakarta: PT Gramedia Pustaka Utama.

Catur, Supatmono. 2009. Matematika Asyik: Asyik Mengajarnya, Asyik Belajarnya. Jakarta: Grasindo.

Clement, Ken dan Ellerton, Nerinda F. 1996. The Newman Procedure of Analysing Error On Written Mathematical Task.

Csaky, A., Szabova, E., dan Nasticka, Z. 2015. Analysis of Errors in Students Solutions of Context-Based Mathematical Tasks. Acta Mathematica Nitriensia, 1, 68-75.

Departemen Pendidikan dan Menengah. 1995. Kamus Besar Bahasa Indonesia. Jakarta: Balai Pustaka.

Depdiknas. 2003. Kurikulum 2004 Mata Pelajaran Sekolah Menengah Pertama dan Madrasah Tsanawiyah. Surabaya: Usaha Nasional.

Fatimah. 2009. Fun Math: Matematika Asyik dengan Metode Pemodelan. Bandung: Mizan Pustaka.

Hudojo, Herman. 1988. Mengajar Belajar Matematika. Jakarta: P2LPTK, Dirjen Dikdi, Depdikbud.

Hudojo, Herman. 2003. Pengembangan Kurikulum dan Pembelajaran Matematika, Common Textbook. Malang: Universitas Negeri Malang.

Kamarullah. 2005. Analisis Kesalahan Mahasiswa D-2 PGMI IAIN Ar-Ranity Banda Aceh tentang Geometri di Madrasah Ibtidaiyah beserta Alternatif Pembelajarannya. (Makalah Ujian tesis). Surabaya: Unesa.

Kementerian Pendidikan dan Kebudayaan. 2016. Matematika SMP/MTs Kelas VII Semester I Edisi Revisi. Jakarta: Kemendikbud.

Khodijah, Nyayu. 2011. Psikologi Pendidikan. Palembang: Grafika Telindo Press.

Komarudin, 1994. Ensiklopedia Manajemen. Jakarta: Bumi Aksara. 
Sumila Eka Yuni Arianti : Analisis Kesalahan Peserta Didik...

Lexy J, Moleong. 2007. Metode Penelitian Kualitatif. Bandung: PT. Remaja Rosdakarya.

Murniati, Nunuk. 2004. Getar Gender, Buku Pertama. Magelang: Indonesia Tera.

Mulyadi, \& dkk. 2015. Analisis Kesalahan dalam Menyelesaikan Soal Cerita pada Materi Luas Permukaan Bangun Ruang berdasarkan Newman's Error Analysis (NEA) Ditinjau dari Kemampuan Spasial. Jurnal Elektrik Pembelajaran Matematika. Vol. 03 No 04 hal. 370-382.

Noor, Juliansyah. 2011. Metode Penelitian : Skripsi, Tesis, Disertasi, dan Karya Ilmiah. Jakarta: Kencana Prenada Media Group. Offirston, Topic. 2014. Aktivitas Pembelajaran Matematika Melalui Inkuiri Berbantuan Software Cinderella. Jogjakarta: CV Budi Utama.

Rokhmansyah, Alfian, S.S., M.Hum. 2016. Pengantar Gender dan Feminisme. Yogyakarta: Garudhawaca.

Ruffendi, E.T. 1988. Pengantar Kepada Membantu Guru Mengembangkan Kompetensinya dalam Pengajaran Matematika untuk Meningkatkan CBSA. Bandung: Trasito

Santrock, John W. 2007. Perkembangan Anak Jidil 2. Jakarta: Erlangga.

Singh, P., Rahman, A. A., dan Hoon, T. S. 2010. The Newman Procedure for Analyzing Primary Four Pupils Errors on Written Mathematical Tasks: A Malaysian Perspective. Procedia Social and Behavioral Sciences, 8, 264271.

Siswandi, E., dkk. 2016. Analisis Kesalahan Siswa dalam Menyelesaikan Masalah Matematika Kontekstual pada Materi Segiempat berdasarkan Analisis Newman Ditinjau dari Perbedaan Gender. Jurnal Elektrik Pembelajaran Matematika. Vol.04 No.07 hal.633-643.

Soedjadi. 2000. Kiat Pendidikan Matematika di Indonesia. Bandung: Dirjen Dikti Depdiknas. Sudjana, Nana. 2001. Penelitian dan Penilaian Pendidikan. Jakarta: Sinar Baru Algesindo. Sundayana, Rostina. 2015. Media Pembelajaran Matematika. Bandung: Alfabeta.

Susanti. 2017. Analisis Kesalahan Siswa dalam Menyelesaikan Soal Cerita Program Linear Berdasarkan Tahapan Newman. Jurnal Ilmiah Pendidikan Matematika. Vol.02 No. 06 Utaminingsih, Alifiulahtin. 2017. Gender dan Wanita Karir. Malang: UB Press.

White, Allan Leslie. 2010. Numeracy, Literacy and Newman's Error Analysis. Journal of Science and Mathematics. Vol.33 No.2 hal.129-148. 
Postulat: Jurnal Inovasi Pendidikan Matematika 